Ariel OrZęeK

Uniwersytet Mari Curie-SkŁodowskiej w Lublinie /

Maria Curie-Skeodowska University

(iD) https://orcid.org/0000-0001-5360-464X

\title{
Nie tylko spór Stańczyka z Wernyhora Polska myśl polityczna doby zaborów w książce Włodzimierza Bernackiego
}

(Rec.: W. Bernacki, O wolności w czasach niewoli. Myśl polityczna polskich elit intelektualnych $i$ politycznych $w$ XIX $i$ XX wieku, wydawnictwo Arcana, seria Arkana Historii, Kraków 2020, ss. 328).

$\mathrm{T}$

ruizmem jest stwierdzenie, że dziewiętnastowieczna polska myśl polityczna rozwijała się w warunkach specyficznych, spowodowanych podziałem państwa, autonomia niektórych jego części i ruchami powstańczymi. Konsekwencje tego stanu rzeczy sa nie do przecenienia. Polska refleksję polityczna tamtej doby ukierunkowywał przede wszystkim problemat niepodległości, stosunku do niej i metod jej odzyskania, a także związany z tym spór o przyczyny upadku Rzeczypospolitej u schyłku XVIII w. Konflikt „białych” z „czerwonymi”, „Stańczyków” z radykałami, szkoły krakowskiej ze szkoła warszawska jest jednak w istocie determinującym polska myśl polityczna i historyczną także współcześnie (bo czymże innym sa gorace spory o wybór polskiej polityki zagranicznej w 1939 r. czy o ocenę decyzji o rozpoczęciu powstania warszawskiego?) sporem o realizm polityczny i romantyzm w narodowych dziejach oraz w polityce zagranicznej. Konflikt ten obrazowo określić można mianem konfliktu Stańczyka z Wernyhorą. Wydawać by się mogło, że polskich publicystów nie interesowały zatem konstytutywne dla europejskich myślicieli kwestie suwerenności narodu, wolności jednostki, prawa własności czy legitymizmu. Mimo że 
Polacy nie mieli w XIX w. twórców na miarę Josepha de Maistre'a, Alexisa de Tocqueville'a, Benjamina Constanta czy Karola Marksa, nie oznacza to jednak, że rodzima refleksja intelektualna zupełnie lekceważyła główne spory ideowe XIX w.

Udowadnia to i przypomina o tym najnowsza książka Włodzimierza Bernackiego, która ukazała się w serii „Arkana Historii” krakowskiego wydawnictwa Arcana, poświęcona deklaratywnie sporom o samo pojęcie i granice wolności ludzkiej w wiekach XIX i XX. Dorobek naukowy Włodzimierza Bernackiego imponuje. Jego prace $z$ zakresu historii myśli politycznej maja często fundamentalne znaczenie dla tej tematyki, a ich Autor ze swoboda porusza się nie tylko w świecie doktryn, lecz także w różnych epokach historycznych. Jest autorem ważnej dla historii myśli politycznej monografii polskiego liberalizmu w dobie zaborów i okresie międzywojennym ${ }^{1}$, opracowania myśli politycznej demokratów i liberałów galicyjskich $\mathrm{w}$ drugiej połowie XIX w. ${ }^{2}$, jak również studiów z zakresu historii myśli politycznej I Rzeczypospolitej ${ }^{3}$. Warto też wymienić ważny szkic dotyczący relacji między konserwatyzmem a realizmem politycznym ${ }^{4}$.

$Z$ pewnościa zatem Autor był przygotowany do realizacji ambitnego zamiaru stworzenia syntezy polskiej myśli politycznej XIXXX w., rozpatrywanej pod katem refleksji nad terminem wolności. Zamysł taki uznać należy za potrzebny, ale i odważny. Pozornie tylko wydaje się, że ograniczenie do tytułowej kwestii „wolności” ułatwia zadanie. Jak zauważa bowiem W. Bernacki, jest to pojęcie wieloaspektowe. W dobie zaborów, okupacji, lat Polski Ludowej, wolność miała różne zabarwienie, dotyczące zarówno polityki wewnętrznej, zagranicznej, jak też i swobody myślowej, wreszcie narodowej tożsamości.

Przyznam jednak, że rozpocząłem lekturę $z$ pewną obawą co do ścisłości wywodów, porównawszy rozmiar książki (328 stron) z jej obszerna tematyką. Analiza treści przekonała mnie jednak, że były to obawy płonne, a narracja cechuje się syntetycznościa wywodu, ale nie uogólnieniem tematyki. Jest to możliwe dzięki przyjęciu

\footnotetext{
${ }^{1}$ W. Bernacki, Liberalizm polski 1815-1939. Studium doktryny politycznej, Kraków 2004.

${ }^{2}$ I d e m, Jednostka, naród, niepodległość. Myśl polityczna demoliberałów galicyjskich (1882-1905), Kraków 1997.

${ }^{3}$ I d e m, Myśl polityczna I Rzeczypospolitej, Kraków 2011.

${ }^{4}$ I d e m, Konserwatyzm a realizm polityczny, [w:] Geopolityka i zasady. Studia z dziejów polskiej myśli politycznej, red. J. Kloczkowski, Kraków 2009, s. 191-202.
} 
przez Autora zasady rozpatrywania poszczególnych, kluczowych zagadnień poprzez analizę sylwetek ideowych poszczególnych myślicieli (w porządku chronologicznym). Jednakże powyższą uwagę odnieść można jedynie do pierwszej połowy deklarowanego zakresu chronologicznego. Recenzowana publikacja bowiem, wbrew tytułowi, dotyczy przede wszystkim „długiego wieku XIX”, tj. okresu ograniczonego cezurami lat 1795-1918. Nawet jeśli przyjąć, że Autor pojęcie wieku XX potraktował dosłownie, należy stwierdzić, że ogranicza się on w swej refleksji maksymalnie do jego dwóch pierwszych dekad, także piszac o myślicielach tworzacych w okresie międzywojennym, traktując lata II Rzeczypospolitej w sposób wybitnie uogólniający. O ile Autor miał prawo wybrać zresztą jako przedmiot refleksji takich, a nie innych myślicieli i publicystów, to sugerując, że książka dotyczy także XX w., winien przynajmniej dokonywać liczniejszych odniesień do międzywojennej, wojennej i powojennej myśli politycznej, na która wszak refleksje omawianych przez niego postaci często w sposób zasadniczy rzutowały. Tytuł książki może więc zwieść czytelnika. Jest to w zasadzie najważniejszy i zasadniczy mankament książki i lepiej stałoby się, jeżeliby jej tytuł mówił o polskiej myśli politycznej okresu zaborów czy lat 1795-1918.

Nie uważam natomiast za wadę ksiażki faktu, że jest ona, jak wspomniałem, zbiorem niejako osobnych szkiców biograficzno-ideowych, przenikniętych rozważaniami na temat polskiego rozumienia wolności w XIX w. Trudno też czynić Autorowi zarzut $z$ tego, że teksty składające się na książkę ukazały się wcześniej jako wstępy do antologii myśli politycznej czy też inspirowane były wcześniejszymi pracami Autora, tym bardziej że za każdym razem jest to odpowiednio zasygnalizowane. Szkoda jednak, że poszczególne szkice nie sa powiązane w sposób narracyjny, odczuwalny jest brak między nimi jakichkolwiek spójników i nawiązań.

Zastrzeżeń nie budzi raczej wstęp, w którym Autor daje wykład swojej wizji dziejów ideowych polskiego wieku XIX. Bernacki wskazuje na jego zasadniczy związek z I Rzeczpospolita, podkreślając rozumienie wolności jako składnika konstytutywnego szlacheckiego republikanizmu. Snując koncepcje kształtowania narodu „od góry” i wskazując na związek wolności $z$ tożsamościa narodowa, stawia kwestię, w jaki sposób ta postszlachecka i inteligencka wizja rozlała się na masy, co, dodać należy, miało zasadnicze znaczenie dla historii okresu międzywojennego i okresów późniejszych. 
W tym inspirującym tekście razi jedynie omyłkowe stwierdzenie o tym, że „Ziemie dawnego Księstwa Warszawskiego, które powstało $z$ ziem zaboru rosyjskiego i austriackiego, trafiły $\mathrm{w}$ ręce pruskie" ${ }^{\text {. W }}$ istocie, jak wiadomo, jedynie część ziem byłego Księstwa Warszawskiego nie tyle trafiła, co powróciła w ręce pruskie, gdyż samo Księstwo powstało $z$ ziem zaborów najpierw pruskiego, a później, w 1809 r. przyłączono doń część ziem zaboru austriackiego. Główna zaś część terytorium tego państwa znalazła się pod władzą carów rosyjskich, którzy, tworząc Królestwo Polskie, dołączyli do swej tytulatury miano królów polskich. To zatem Rosjanie kosztem Prusaków i Austriaków, a nie Prusacy kosztem Rosjan i Austriaków, wzbogacili się terytorialnie dzięki kongresowi wiedeńskiemu.

Kolejne szkice biograficzne Autor poświęcił zarówno czołowym myślicielom, takim jak Aleksander Świętochowski czy Michał Bobrzyński, jak i mniej znanym, jak Tadeusz Romanowicz. Przegląd dokonany przez W. Bernackiego wydaje się pełny, jeśli rozumieć jako cel Autora analizę publicystów wpisujacych się w szeroko rozumiany nurt myśli liberalnej, uzupełnionej o refleksję konserwatywną, pozytywistyczna i realistyczną. Tytuł książki mówi wprawdzie ogólnie o „wolności”, problematem tym nie zajmowali się jednak tylko liberałowie czy pozytywiści. Oczywiście trudno wymagać od Autora stworzenia „pocztu” polskich myślicieli. Wybrane przez niego przykłady sa w zasadzie reprezentatywne, dostrzegając jednak znakomita orientację W. Bernackiego w meandrach historii polskiej myśli politycznej, z żalem przyjąc należy, że nie opracował on szkicu poświęconego któremuś $z$ ojców polskiego nacjonalizmu: Romanowi Dmowskiemu, Zygmuntowi Balickiego czy Janowi Ludwikowi Popławskiemu.

Przekonany przy tym jestem, że przygotowane przez Autora analizy spełnia oczekiwania zainteresowanych polskimi dziewiętnastowiecznymi sporami ideowymi. Prezentuja one bowiem, mimo powyższych zastrzeżeń, wachlarz poglądów i refleksji politycznych. Wawrzyniec Surowiecki, bohater pierwszego szkicu, był w zasadzie konserwatywnym liberałem. Apologeta wolnego rynku, ale i rzecznik ograniczonej pomocy socjalnej sprzyjającej równości szans, państwo widział jako „nocnego stróża”, którego kompetencje wynikały $z$ porządku naturalnego. Egalitaryzm postrzegał jako krok do, nienazwanej tak jeszcze, wszechpolskości, a szczególnie

${ }^{5}$ W. Bernacki, O wolności $w$ czasach niewoli. Myśl polityczna polskich elit intelektualnych i politycznych $w$ XIX $i$ XX wieku, Kraków 2020, s. 8. 
interesujaca jest jego koncepcja wolnej wymiany handlowej, nieograniczonej względami polityki międzynarodowej. Jego koncepcja własności, znacząco wyprzedzająca swoją epokę, zdawała się mieć echa w wieku XX, przykładowo w neokonserwatywnym środowisku „Buntu Młodych" i „Polityki”, ale też w sporach o katolicki radykalizm po wojnie ${ }^{7}$. Ogólnie wydaje się, że „reformowany liberalizm” Surowieckiego w dużej mierze wpływał na środowiska „młodokonserwatywne” Polski międzywojennej ${ }^{8}$. Interesujące też, że publicysta swoja refleksję odnosił także do czasów staropolskich, Autor nie porusza jednak bliżej kwestii tego, czy wiązał swe rozważania ze współczesna mu sytuacja polityczną.

Z koncepcjami Surowieckiego korespondował Józef Supiński, nie tylko w swej antropologicznej de facto teorii społeczeństwa, lecz także w sprzeciwiającej się statokracji wizji liberalizmu i decentralizacji. Podkreślając, że to wolny rynek reguluje ceny, nie tracił jednak $z$ oczu konieczności zabezpieczenia przez państwo tego mechanizmu w postaci protekcjonizmu, pomocy w kredytach i wsparcia dla zbytu, słowem: stworzenia warunków „prorozwojowych”. O ile Supiński troszcząc się o rozwój zbiorowości narodowej, był $\mathrm{w}$ pewnym sensie prekursorem rozwiąań pozytywistycznych, o tyle zdawał sobie sprawę, że nie można mówić o pełnej wolności człowieka bez rozwoju jego narodowej tożsamości. W przypadku tej sylwetki nie zastrzeżenia do Autora, lecz uwagę polemiczna mam jedynie do oceny koncepcji Supińskiego, głoszącej, że rozwój życia partyjnego i politycznego prowadzić mógł do fanatyzmu, co łagodzić mogła oświata. Zdaniem W. Bernackiego była to proklamacja postpolityki, ocenianej przez niego jako szkodliwa9 ${ }^{9}$ Czy jednak

6 J. Frankowski, W obronie zagrożonej własności, „Bunt Młodych” 1934, R. V, nr 9(58), s. 5; ide m, Sprawiedliwość społeczna, „Bunt Młodych” 1934, R. V, nr 16(65), s. 4.

7 K. Łubieński, Upowszechnienie własności, „Odnowa” 1946, R. I, nr 9, s. 1-2; K. Studentowicz, Kontrola zużycia dochodu społecznego, „Tygodnik Warszawski” 1947, R. III, nr 17, s. 2; id e m, Gospodarka planowa w koncepcji katolicko-społecznej, „Tygodnik Warszawski” 1948, R. IV, nr 4, s. 4; ide m, Ojcowie Kościoła a kapitalizm, „Tygodnik Warszawski” 1948, R. IV, nr 29, s. 1-2.

${ }^{8}$ R. Habiels ki, Doką nam iść wypada? Jerzy Giedroyc. Od „Buntu Młodych" do „Kultury”, Warszawa 2006, passim; M. Kró1, Style politycznego myślenia. Wokół „Buntu Młodych” i „Polityki”, Paris 1979, passim; S.J. Rostworowski, Konserwatyści. Dzieje ruchu zachowawczego w II RP. Kres czy istnienie?, Warszawa 2018, s. 59-60, 114-116, 130-162, 189-194, 214-217, 233-236, 293-302; S. Paczos, Państwo i naród w myśli politycznej polskich konserwatystów do 1939 roku, Kraków 2009, s. 243-296.

9 W. Bernacki, O wolności..., s. 58-59. 
czymś złym jest „łagodzenie politycznych obyczajów” i czy od razu oznaczać to musi postpolitykę? Podobnie nie mogę w pełni zgodzić się $z$ tezą, według której nauka, w sposób niezamierzony co prawda, stała za faszyzmem i komunizmem. O ile jeszcze marksizm w swej teorii można uznać za wulgaryzację nauk społeczno-ekonomicznych, o tyle faszyzmy, nie tylko te najbardziej znane, włoski i niemiecki, lecz także rumuński, węgierski czy francuski, były synteza ulicznych teorii spiskowych, praktyki polityki masowej i wieloaspektowego kryzysu XX w. Adolf Hitler, będący samoukiem i wielbicielem wszystko tłumaczacych narracji, doprawdy niewiele miał wspólnego $z$ nauka. Faszyzm był w swej istocie doprowadzona do ostateczności konsekwencja „buntu mas” ${ }^{10}$ przeciwko elitom i ich afirmacji nauki.

Koncepcje takie jak Surowieckiego czy Supińskiego w dużej mierze były jednak rezultatem teoretycznych sporów. Przeciwnie rzecz się miała $z$ refleksjami związanego początkowo $z$ nurtem romantycznym w Wielkopolsce Karolem Libeltem. Teoretyk państwa narodowego traktowanego jako źródło wolności był jednocześnie zwolennikiem polsko-niemieckiej współpracy wymierzonej w Rosję. Szczególnie interesujące są też jego koncepcje antropologiczne o ambicji jako motorze działań ludzkich w kontekście indywidualizmu i tradycyjnej cnocie zapobiegającej anarchii w $\dot{z} y-$ ciu wewnętrznym.

O Surowieckim, Supińskim czy nawet Libelcie napisać można wiele nowego, ale czy rzecz ma się tak samo z klasykami polskiej idei konserwatywnej, Walerianem Kalinką i Michałem Bobrzyńskim? Piszac o tych wielkich nazwiskach myśli stańczykowskiej, W. Bernacki trafnie podkreślił rzeczywiste cele krakowskiej szkoły historycznej - wzmacnianie narodu przez obiektywna, krytyczna ocenę narodowych dziejów. W przypadku Kalinki przejawiało się to w negatywnej ocenie polityki zagranicznej Sejmu Czteroletniego i szczególnie obrazoburczej w polskiej tradycji krytyce politycznych skutków Konstytucji 3 maja. Wizja tego historyka miała zasadniczy wpływ na orientacje prorosyjska w XIX i XX w, w tym na nawiazujące otwarcie do jego myśli Dzieje głupoty w Polsce Aleksandra Bocheńskiego ${ }^{11}$, będące najważniejszym manifestem polskiego dwudziestowiecznego realizmu politycznego. Kalinka nie był jednak wolny

${ }^{10}$ J. Ortega y Gasset, Bunt mas, Zakrzewo 2020, passim.

${ }_{11}$ A. Bocheńs ki, Dzieje głupoty w Polsce. Pamflety dziejopisarskie, Warszawa 1947. 
w swej refleksji od aspektów niematerialnych. Zaskakująca wydaje się, trafnie uchwycona przez Autora recenzowanej pracy, synteza politycznego realizmu i religijnego konserwatyzmu przy przekonaniu o szkodliwości oświeceniowej apologii jednostki dla ustroju państwa, także w kontekście tragizmu dziejów I Rzeczypospolitej. Bernacki, zarysowując portret Kalinki jako ultramontańskiego pozytywisty, postawił go niejako w opozycji do postaci „ostatniego Stańczyka"12, Michała Bobrzyńskiego. Szkic mu poświęcony, najlepszy chyba w całej książce, także zawiera szereg informacji o jego sporach ze starszymi konserwatystami, co jest przyczynkiem do analizy historiozofii Bobrzyńskiego. Interesujące jest też zaznaczenie przyczyn zasadniczej rozbieżności między namiestnikiem Galicji a Narodową Demokracją. Bobrzyński, który zmarł w roku 1935, prowadził w II Rzeczypospolitej działalność nie tylko naukowa i ideowa, lecz także polityczną i na jego przykładzie widać najlepiej, jak wielką szkoda dla książki jest potraktowanie przez jej Autora tego okresu w marginalny sposób. Bobrzyński wszak swoja syntezę dziejów Polski, będąca jednym z najważniejszych dzieł polskiej historiografii, zdołał doprowadzić aż do początku Polski niepodległej ${ }^{13}$. Trudno zrozumieć, dlaczego Autor w sposób skrótowy przedstawił jego refleksję o dziejach porozbiorowych, w ogóle nie zwracając uwagi na ocenę przez Bobrzyńskiego historii narodowej po powstaniu styczniowym. $Z$ obowiązku zaznaczam też następujaccy lapsus: „Za Szujskim autor Dziejów... wprowadza do swego działa pojęcie liberum conspiro, któremu nadaje znaczenie analogiczne do XVIII-wiecznego liberum conspiro"14 (chodziło zapewne o liberum veto). Ogólnie jednak szkice o Kalince i Bobrzyńskim stanowia nowe, wartościowe ujęcie w polskiej historiografii.

Tadeusz Romanowicz to chyba najmniej znany bohater publikacji W. Bernackiego. Ten galicyjski demokrata, egalitarysta i organicznik miał tymczasem wyjatkowo zwarty system myślowy, odnoszący się wprost do położenia sprawy polskiej. Walkę o niepodległość utożsamiał $z$ duchem narodu, głosząc, że naród wyrzekający się swej wolności musi zginąć. Niemniej dostrzegał różne drogi do suwerennego bytu państwowego, odmawiał jednak

12 Według określenia Waldemara Łazugi (Ostatni Stańczyk. Michał Bobrzyński-portret konserwatysty, Torun 2015).

${ }_{13}$ M. Bobrzyński, Dzieje Polski w zarysie, t. I-II, Warszawa 1927; idem, Dzieje Polski w zarysie, t. III (Dzieje porozbiorowe), Warszawa 1931.

${ }^{14}$ W. Bernacki, O wolności..., s. 265. 
realistom intencji niepodległościowych dlatego, że je taktycznie ukrywali. W mym przekonaniu (ale absolutnie nie w przekonaniu W. Bernackiego) było to uproszczenie, umacniajacce szkodliwą narrację „wszystko albo nic”, o którą rozbijały się próby ugody $z$ zaborcami. Była ona jeszcze bardziej zwulgaryzowana przez romantycznych niepodległościowców, którzy twierdzili często, że wyrzeczenie się działań insurekcyjnych jest decyzja podjęta ostatecznie, która nigdy nie zostanie zmieniona, niezależnie od okoliczności. Mało realna była też koncepcja Romanowicza, który ugodę $z$ jednym zaborca wymierzona $\mathrm{w}$ pozostałych postulował jedynie w razie otrzymania konkretnych koncesji. Jeśli tych by zabrakło, lepsza była bierność. Była to wizja lekceważąca zasadnicze prawidła geopolityki środkowoeuropejskiej, w której konflikt państw niemieckich $z$ Rosja był najlepsza koniunktura dla sprawy polskiej i sam w sobie był czynnikiem, który musiał spowodować polepszenie położenia narodu polskiego ${ }^{15}$. Romanowicz był przywiazany do ideałów, lecz nie do realiów: twierdził, że Polacy mieli prawo buntować się w dobie powstań przeciwko Rosji, gdyż ta łamała ich prawa, tak, jakby istniała równowaga sił między polską autonomią a potężnym państwem carów. Przejęty antyrosyjskim kompleksem Romanowicz bronił zupełnie nierealnej wykładni międzynarodowego położenia sprawy polskiej, wierząc w pomoc mocarstw zachodnich. Był w swej wizji publicysta nawiązującym już wyraźnie do zwrotu neoromantycznego w polityce polskiej, którego najpełniejszym wyrazem była lewica niepodległościowa Józefa Piłsudskiego.

Rozpatrywanie prozaików także pod kątem ich twórczości publicystycznej jest $z$ pewnościa potrzebne, czego dowiódł Autor w szkicu poświęconym Bolesławowi Prusowi. W kontekście pozytywizmu przede wszystkim trzeba podkreślić rozważania W. Bernackiego o Aleksandrze Świętochowskim. Zarysowując jego propozycje w sprawie polskiej (szczególnie interesujące są obszerne rozważania tego nestora polskiego pozytywizmu nad formami autonomii ziem polskich), Autor nie zlekceważył również antropologicznych i filozoficznych refleksji bohatera szkicu. Świętochowski traktował bunt jako źródło postępu, ale we władzy państwowej, o ile szanowała wolność, widział źródło zachowania wolności, która mogła, na skutek natury ludzkiej, przerodzić się w coś zgoła odmiennego. Świętochowski, rozumiejąc ducha epoki, wysnuwał interesujące koncepcje dotyczace prawa pracy, w kwestiach natury ideowej

${ }^{15}$ Por. W. Studnicki, Sprawa polska, Poznań 1910. 
wyraźnie też zaznaczał, czym różni się konserwatyzm od liberalizmu. Bernacki zasygnalizował też niechęć Świętochowskiego do Józefa Piłsudskiego. Ze swej strony chciałbym dodać, że temat ten jest interesujacy, ponieważ to w zasadzie dzięki swemu przeciwnikowi przyszły Marszałek poznał swojego najbliższego współpracownika - Kazimierza Sosnkowskiego. Według relacji tego ostatniego dzięki znajomości z synem Aleksandra, Ryszardem, mógł spotkać się z nim i wysłuchać jego opowieści o Piłsudskim, która zafascynowała go do tego stopnia, że od tej pory zapałał pragnieniem poznania Piłsudskiego i współpracy z nim. Jeśli wierzyć Sosnkowskiemu, $z$ tego też powodu porzucił plany studiów w stolicy Rosji i zwiąał się z Polską Partia Socjalistyczną ${ }^{16}$. Wątków zwiąanych ze Swiętochowskim po 1918 r. jest zresztą więcej, szkoda zatem, że tak mało pisze o nich Autor, rzadko też nawiązując do współczesności w swej analizie epoki (a przecież bardzo interesujące jest jego porównanie zaskoczenia skutkami politycznymi rewolucji 1905 r., w społeczeństwie polskim z zaskoczeniem Polaków przełomem roku 198917). $Z$ pewnością szkic wzbogaciłby refleksje W. Bernackiego na temat stosunku czołowego polskiego pozytywisty do II Rzeczypospolitej, której schyłku niemalże doczekał (zmarł w 1938 r.). Chyba też Świętochowski nie debiutował publicystycznie, jak pisze Autor, w 1859 r. ${ }^{18}$, miałby wtedy bowiem zaledwie 10 lat.

Książkę zamykają dwie krótsze sylwetki publicystów, mierzących się już z wyzwaniami rodzącej się epoki najnowszej. Wojciech Dzieduszycki skupiał się na analizie dziejów cywilizacji, ze szczególnym uwzględnieniem przyczyn jej upadku. Był, podobnie jak José Ortega y Gasset ${ }^{19}$, przeciwnikiem awansu mas, uważajac, że prowadzi on do wulgaryzowania przez nich kultury. Chociaż był mimo wszystko optymista, twierdząc, że cywilizacja europejska przetrwa chaos, w jaki wkracza, w istocie diagnozował, piszac na przełomie

${ }^{16}$ J. Sosnkowska, W.T. Kowalski, W kręgu mitów i rzeczywistości, Warszawa [b.r.w.], s. 14; K. Sosnkowski, Materiały historyczne, red. J. Matecki, Londyn 1966, s. 565-566. Kończąc ten wątek, można dopowiedzieć, że w późniejszych latach Sosnkowski i Ryszard Świętochowski darzyli się wielka niechęcią, na co wpływ miały ich związki rodzinne i wynikające $z$ nich konflikty (ich żony były rodzonymi siostrami). Miało to swoje konsekwencje w czasie II wojny światowej, gdy Świętochowski, stronnik gen. Władysława Sikorskiego, był organizatorem Centralnego Komitetu Organizacji Niepodległościowych, wymierzonego w Związek Walki Zbrojnej kierowany przez gen. Sosnkowskiego.

17 W. Bernacki, O wolności..., s. 240.

18 Ibidem, s. 210.

19 J. Ortega y Gasset, op. cit., passim. 
XIX i XX w., wiele problemów ludzkości w wieku XXI. Polemizujacy z Dzieduszyckim Teodor Jeske-Choiński widział z kolei dla ludzkości szansę w postępie, chociaż nie był jego bezkrytycznym zwolennikiem. Lektura tego ostatniego szkicu pozostawia jednak niedosyt, zwłaszcza wobec świadomości, że jego bohater wiele ze swych poglądów wyraził w swej twórczości historyczno-prozatorskiej, która warto byłoby poddać szerszej analizie ${ }^{20}$.

Dużym zaskoczeniem jest brak jakiegokolwiek zakończenia, nawet w postaci krótkich wniosków sumujacych książkę. Autor, po dokonanym przeglądzie sylwetek twórców polskiej myśli politycznej okresu rozbiorów, nie wskazał kierunków jej ewolucji, nie porównał ze soba poszczególnych twórców, nie wspominając już o odniesieniach do epoki zaczynającej się w 1918 r. Stało się to $z$ wielka szkoda dla publikacji, która opatrzona takim podsumowującym rozdziałem $z$ pewnością zyskałaby na wartości.

Książka jest napisana dobrym językiem, niekiedy tylko pojawiają się niezręczności stylistyczne, zwłaszcza na stronach 212 i 215. Nie moga one jednak, podobnie jak wskazane merytoryczne błędy, wpływać na jej ocenę. Jest ona poważnym i interesującym studium z zakresu dziewiętnastowiecznej myśli politycznej, udowadniającym, że jej Autor wykazuje dogłębną znajomość uwarunkowań ideowych epoki, zarówno w aspekcie polskim, jak i światowym, często rysujacc odpowiednie tło kontekstowe dotyczące europejskiej myśli politycznej. Należy dodać, że W. Bernacki, poruszając problematykę tak istotną również współcześnie, zdołał zachować obiektywizm. Nie unikał swej oceny analizowanych sylwetek ideowych, nie wyrażał jednak swych osobistych, politycznych poglądów. Że jest to zadanie dla historyka myśli politycznej trudne, dowodzi znakomita, ale wybitnie politycznie zaangażowana książka Jacka Bartyzela o konserwatyzmach legitymistycznych w XIX i XX w. ${ }^{21}$ Dobrze by się stało, gdyby $W$. Bernacki rzeczywiście rozszerzył swoje rozważania na wybranych myślicieli i publicystów XX w. zajmujących się tematyką wolności zarówno w II Rzeczypospolitej, jak

${ }^{20}$ T. J es ke-Choiński, Tiara i korona, t. I-IV, Warszawa 1900; ide m, Ostatni Rzymianie. Powieść z czasów Teodozjusza Wielkiego, t. I-II, Warszawa 1897; idem, Gasnace słońce. Powieść z czasów Marka Aureliusza, t. I-IV, Warszawa 1905.

${ }^{21} \mathrm{~J}$. B artyze1, „Umierać, ale powoli!”. O monarchistycznej i katolickiej kontrrewolucji w krajach romańskich 1815-2000, Kraków 2006. 
i w okresie okupacyjnego i komunistycznego zniewolenia jednostki i zbiorowości. Ma bowiem, jak dowodzi tego recenzowana książka, wszystkie ku temu kwalifikacje.

\section{Bibliografia}

\section{ŹRódeA DRUKOWANE}

Sosnkowska J., Kowalski W.T., W kręgu mitów i rzeczywistości, Warszawa [b.r.w.]. Sosnkowski K., Materiały historyczne, red. J. Matecki, Londyn 1966.

\section{Publicystyka polityczna}

Ortega y Gasset J., Bunt mas, Zakrzewo 2020.

Studnicki W., Sprawa polska, Poznań 1910.

\section{Publikacje prasowe}

Frankowski J., Sprawiedliwość społeczna, „Bunt Młodych” 1934, R. V, nr 16(65), s. 4. Frankowski J., W obronie zagrożonej własności, „Bunt Młodych” 1934, R. V, nr 9(58), s. 5.

Łubieński K., Upowszechnienie własności, „Odnowa” 1946, R. I, nr 9, s. 1-2.

Studentowicz K., Gospodarka planowa w koncepcji katolicko-społecznej, „Tygodnik Warszawski” 1948, R. IV, nr 4, s. 4.

Studentowicz K., Kontrola zużycia dochodu społecznego, „Tygodnik Warszawski” 1947, R. III, nr 17, s. 2.

Studentowicz K., Ojcowie Kościoła a kapitalizm, „Tygodnik Warszawski” 1948, R. IV, nr 29, s. 1-2.

\section{Proza}

Jeske-Choiński T., Gasnace słońce. Powieść z czasów Marka Aureliusza, t. I-IV, Warszawa 1905.

Jeske-Choiński T., Ostatni Rzymianie. Powieść z czasów Teodozjusza Wielkiego, t. I-II, Warszawa 1897.

Jeske-Choiński T., Tiara i korona, t. I-IV, Warszawa 1900.

\section{OpRacowania}

Bartyzel, J. „Umierać, ale powoli!”. O monarchistycznej i katolickiej kontrrewolucji w krajach romańskich 1815-2000, Kraków 2006.

Bernacki W., Jednostka, naród, niepodległość. Myśl polityczna demoliberałów galicyjskich (1882-1905), Kraków 1997. 
Bernacki W., Konserwatyzm a realizm polityczny, [w:] Geopolityka i zasady. Studia z dziejów polskiej myśli politycznej, red. J. Kloczkowski, Kraków 2009, s. 191-202.

Bernacki W., Liberalizm polski 1815-1939. Studium doktryny politycznej, Kraków 2004.

Bernacki W., Myśl polityczna I Rzeczypospolitej, Kraków 2011.

Bernacki W., O wolności w czasach niewoli. Myśl polityczna polskich elit intelektualnych i politycznych w XIX i XX wieku, Kraków 2020.

Bobrzyński M., Dzieje Polski w zarysie, t. I-II, Warszawa 1927.

Bobrzyński M., Dzieje Polski w zarysie, t. III (Dzieje porozbiorowe), Warszawa 1931.

Habielski R., Dokad nam iść wypada? Jerzy Giedroyc. Od „Buntu Młodych” do „Kultury”, Warszawa 2006.

Król M., Style politycznego myślenia. Wokół „Buntu Młodych” i „Polityk»”, Paris 1979.

Łazuga W., Ostatni Stańczyk. Michał Bobrzyński-portret konserwatysty, Torun 2015.

Paczos S., Państwo i naród w myśli politycznej polskich konserwatystów do 1939 roku, Kraków 2009.

Rostworowski S.J., Konserwatyści. Dzieje ruchu zachowawczego w II RP. Kres czy istnienie?, Warszawa 2018.

NOTKA O AUTORZE:

Dr Ariel Orzełek - adiunkt w Instytucie Historii Uniwersytetu Marii Curie-Skłodowskiej w Lublinie.

Zainteresowania naukowe: środowiska katolików świeckich w Polsce Ludowej, historia myśli politycznej, biografistyka. Autor monografii Poszukiwanie modelu realizmu politycznego. Myśl i publicystyka Aleksandra Bocheńskiego oraz licznych artykułów, opublikowanych m.in. w „Dziejach Najnowszych” i „Kwartalniku Historycznym".

ఐ ariel.k.orzelek@gmail.com 